\title{
IMPACT OF SFDP UNDER ADB ON INCOME GENERATION ACTIVITIES AT BOKHIM VDC BHOJPUR
}

\author{
Tirtha Kumar Shrestha
}

\section{INTRODUCTION}

Especially Nepal is an underdeveloped country. Underdevelopment countries are characterized by acute poverty, low per capita income, inequitable distribution of wealth, very low standard of life and low taxable capacity. The scope of additional taxation for financing the development expenditure is limited due to the very nature of the VDC's. Besides the heavy taxation in such a situation would hamper the very prupose of development by curbing consumption and discouraging the productive incentives. Moreover the huge amount of development expenditure is so heavy that in no circumstance, it can be met by taxation. The expenditure requirement of the government's growing due to significant increase in government activities both intensively and extensively.

The main purpose of the study is to acquaint with the role of Small Farmers Development Programme of ADB in income generating programme in Bokhim Village Development Committee. In this connection, I have tried my best to concentrate on the growing activities of small farmer programme of ADB in recent years. One of the important objectives of which is to assist in the process of economic growth of Bokhim Village Development Committee. The need of building financial infrastructure for Nepal income growth is not only unquestionable in the VDC but also we want to controlling mechanism in the borrowing system through which resources could be divided to the concerned sector and channeled for income growth. I believe on the efficiency of sma.. farmer development programme of $\mathrm{ADB}$ and hope that the purpose can be fulfilled through it.

There are great rural poor groups, so there must be submitted in different development programmes which are conducted in different models. But in Nepal, conducting programme has not played vital role for the economic development so that development programme has not reached in rural level and rural people have not increased production and productivity, so they become poorer and poorer. From the local level, tried to remove the social and economic difficulties for the rural development. Many countries think about special programme in international level for the development of special groups of different developing countries. In the $70^{\text {th }}$ decade, an international conference directed to conduct in the "Small Farmer Development Programme" in different developing countries. In Nepal, this programme was started from 2032 B.S. in 


\section{IMPACT OF SFDP UNDER ADB}

two places as a test term by ADB. The result was found successfully by this testing programme, then "Small Farmer Development Programme" was established in different parts of the country. Now the numbers of "Small Farmer Development Programme" have become 388 all over the country, which have Served 631 VDC's, where 1,75,653 small farmer families are included. From the beginning to 2053/054 B.S., this programme has invested Rs. 5 arab 26 crore amount loan for the development of economic condition of small farmers and creation for self employment to increase income in rural. But in this period the loan collection had only Rs. 2 arab 72 crore amount of invested loan (Acharya: 1980).

In our country the number of females is approximately half of total population, so female also must be included in development programmes. Therefore, Small Farmer Development Programme has conducted female development programme. The aim of this programme was established "Female Small Farmer Development Programme" in 5 development region on regional level. Still now there are three "Female Small Farmer Development Programme" has established and other two are 5363 female groups are working in different service of project in which 45,693 number of female are included in this female group (Agrawal: $1081 \&$ Suwal: 1980).

\section{THE CONCEPT AND PURPOSE OF SFDP AND $\dot{A D B}$, NEPAL}

The concept of SFDP of ADB has been changing during recent years in terms of its role and policies, its relation with the small farmer and the project, its attitude towards the creation of self employment and economic development etc. there my attention in this study would be on its role, policies and attitudes to income growth. For getting this programme, the following concepts and purposes were kept:

1. To bring the importance in the economic and social condition of one group in the exception of persons by conducting the development programme by the way of group conception and group medium.

2. To make the outline structure of development by collecting the rural public participation by the group medium.

3. It is to provide the equal opportunity for rich and poor people from the agencies of developmental sources and also to develop in the capacity of service taking and using of the poorer ones.

4. It is to modernize the present local standard of expertness and to create the opportunities of extra income by enlarging new expertness and technology. 
5. By conducting the programme for a fixed period and fixed place and by improving properly in the economic and social standard of the involved community. It is to emphasize upon the self-dependency and to transfer the planning to another area after achieving the sign of standard increasing.

To fulfill the above aims, this programme took the form of nation wide and the Small Farmers Development Programme was established in all seventyfive districts of this country. At that very period, it was declared by the government as a national programme (ADB: 1979).

\section{METHODOLOGY}

The study mainly will be attempted to make a general survey in investment of SFDP on Bokhim Village Development Committee for the income-generating programme. It also tries to give a glimpse on investment of SFDP, which can play an important role in the economic and social development of Bokhim VDC. The SFDP loan investment programme was started $18^{\text {th }}$ Kartik 2036 B.S. in this VDC. In short span of time, however the SFDP has played very important role for income generation of farmers. So it also tries to evaluate the effect of loan investment in different areas. The study of secondary data will be under consideration to treat the different issues and to evaluate the impact of loan investment in different field of economy. Primary data and information will be considerable for the analysis and conclusion so the study is based on primary and secondary data and information. The secondary data are collected from official records and primary data and information are collected from related area by observation and interview.

\section{EMPIRICAL ANALYSIS}

Financial development is one of the key indicators of economic development of any village and any country. Financial institution provides resources for investment, which is needed for economic development. In the financial sector, new institutions and instruments as well as financial innovations emerge in response to the need of the expended economy.

In is clear that. Nepal is an underdeveloped country. It is formed by more than 4 thousand village developing Committees. Among this village development committee. Bokhim is one of the VDC's which is also underdeveloped. So there is a need for additional capital investment to obtain higher rate of economic growth. Domestic savings and loans are the two principal and stable source of capital but it is not sufficient for economic development of Bokihim VDC. 
For the fulfillment of the source of capital, the SFDP was established in BS 2036 Kartik $18^{\text {th }}$. At that time the SFDP was working in Bokhim VDC

activity. The SFDP organized different communities for the investment of loan. There must be minimum 5 members in community. The community decides the investment area and prepares the proposal of loan demand. When the farmer community will introduce the proposal of loan demand then the SFDP checked the proposal, the purpose of loan and method of investment and return of investment is right or not. If the SFDP considered as positive for the investment of loan, they inspection the deposited land, house and certain amount of loan. the SFDP granted the loan according to proposal or declining the amount. There is collective responsibility in the loan because the loan is invested by collective decision. This system has been practiced in practical life among the people of Bokhim VDC. So the process of loan investment of the SFDP has been popular. A large number of small farmers are taking necessary loan having including in the community. There are two types of communitics, which are:

1. Male community

2. Female community

Of the above two, male community is organized by males and females members and work all round for income generating and growth. But female community is organized by female members only and it works only for the female activities or it incentives for the employment of women and increases the income of female group. There are 41 male communitics and 27 fcmalc communities organised in Bokhim VDC till last Paush 2054 from the beginning.

In the above two communities there are 229 members in male community and 134 members in female community. In this way, the total numbers of debtors are 363 in Bokhim VDC. Among these members. they have taken different types of loans such as fooding, cash crops, husbandry, agriculture tools etc. So the total number of debtors has been 750 till last Paush 2054 B.S. Among the total number of debts have been exceeded in the certain time period. which is going to change as a form of bad debt. Their 68 communities including both among them 26 communities have become inactive because they exceed the certain time period if the invested loan. They could not return the loan. this means that they have been failured to do earning the income or they have misused the loan.

Among the 68 communities there are 26 community which are unsucceeded to return the loan and other 16 male community which have 55 members are inactive. They have not taken any activities or they are not coming in the contact of SFDP and they are not taking any kind of loans. There are 4 female communities, which have 20 members, are inactive like above 26 male communities. In this way, there are 22 communities only working actively or taking part in income generating work. Generally the community of ward no. 2 . 
3 and 4 are working actively and taking part in income generating work as they are earning income by different works. They are invested the loan in cash crops, such as vegetable production, milk production etc.

Since the last year the SFDP has taken deposit of money of granted loan at the rate of $5 \%$ in invested loan. In this way the organized community decide to take loan for certain purpose then SFDP granted loan checking the aim of loan and asset of deposit. Then after 5\% amount of granted loan should be deposited in the SFDP, in this amount the SFDP gives interest to the depositor. For this purpose, all the organized communities and member are included and Rs. 455 amount have been deposited till the last Paush 2054 B.S.

In their light, one of the main objectives of SFDP is to raise the level of income of the small peasants' members, some of the few people felt that the SFDP has contribution to increase the agriculture the production where as a vast majority of people felt that the SFDP has no contribution to raise the agriculture production. The type of contribution received by the small peasants' members from the SFDP the available of oxen, the provision of agriculture training, the availability of improved seeds and inputs. But the people are saying 'No improvement in agriculture production.' After the introduce of SFDP, it is the failure to manage the regular agriculture training due to the lack of initiative taken by the SFDP for the development of agriculture. The small farmers take loan for being able to cultivate their respective lands in time' and 'the development of animal husbandry.' The small farmers have been benefited by the agriculture loan provided under SFDP for being able to cultivate in time. On the other hand. development of animal husbandry is found to be the highest in the case of Bokhim VDC. Keeping of livestock is an integral part of the Nepalese way of life, irrespective of cast, creed, wealth and ecological regions of the country. Keeping in view of this reality, SFDP has come forward with an aim to develop livestock programme. The sinall farmer households of Bokhim VDC are found to be more benefited both in the consumption of milk, curd, ghee and their sale after the introduction of SFDP. The number of benefited households are more in wards nos. 2, 3 and of Bokhim VDC in reason for getting benefit by the sale of milk, curd and ghee all the wards nos. 2, 3 and 4 peoples opined that it is due to the availability of loan from the SFDP for the purchase of cows and buffalo's. It is quite close to Bhojpur Bazar to sell the production. The people experienced some troubles in regard to market for these things because here is no transport facility. The SFDP is unable to bring any improvement in food consumption of the small farmer households. So we can say that the programme has not been successful to bring desired changes in the quantity of life of the small farmers. But the SFDP has created favourable environment for increasing the volume of savings by reducing expenditure. Some of the people's expenditure has been increased by the increases of their income (NRB: 1982). 


\section{IMPACT OF SFDP UNDER ADB}

Out of the total population 3202 of Bokhim VDC $34.9 \%$ are found to be literate, which is greater than the national average. However, the literacy rate for

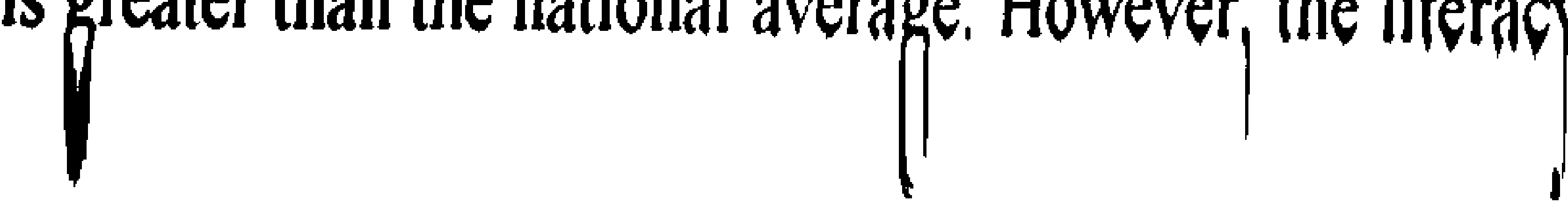

the males and females are $49.2 \%$ and $20.5 \%$ respectively. This shows that the rate of literacy for the male is about 3 times greater than that of female. The SFDP has contributed in the construction of roof of the various primary schools SFDP has conducted adult education programme in different wards of the VDC in different times for removing the illiterate. Although there is a large percentage of small farmers illiterate, poor and ignorant of development opportunities in Bokhim VDC. One of the important activities of the SFDP is to provide different type of training's so that the small farmers families can raise their living condition and also the level of the of their income. Accordingly, the numbers of training programmes are being arranged in Bokhim VDC. However, the quantity and coverage of these training are seemed to be for below to meet the expressed objectives. The major benefits of agricultural training, which the small farmers received, are: 'to apply the new methods of cultivation, proper use of agricultural inputs and cultivation of vegetables. The public health sector training is found to be successful mainly in creating consciousness among the small farmers for keeping their house clean and for keeping good health of the family members. The women training programme is found to be successful basically in the field of increasing family income, employment, childcare and cleanliness of houses. The important activities of SFDP are related to sanitation, health and nutrition. The SFDP has organized mobile health camp in different times in the VDC for creating health consciousness and also for curing the diseases suffered by the small peasants members. The major works done by the SFDP for improving the sanitary condition of the small farmer households includes construction of pit latrines, improvements done around the source of drinking water and raising consciousness for cleaning the house and so adopt the family planning programme for small families. The SFDP has been made two water tanks to provide the additional drinking water facilities to the small farmers. But one water tank has not successful due to technical difficulties, another one is used by the different houses.

The SFDP has provided the loan for the development of cottage industry but the loan and other technical facility has not provided the sufficient amount. So the SFDP seems to have done the very little so far the development of cottage industry in Bakhim VDC. There are no management for the development of cottage industry lack of interest of concerned official and lack of interest of local people seem to have been neglected by SFDP in Bokhim VDC. The generation of employment opportunities under the various development activities undertaken by the SFDP has not found in Bokhim VDC. So the SFDP has been able to do very little in the field of socio-economic development front. Regarding the employment of small peasants labour force in different forms and non-form activities, it has been found that the small farmer families are 
comprising both male and female to have been involved in work annually in Bokhim VDC.

The investment of the SFDP of Bokhim is as follow in different sector in following years:

Table - 1: The investment, purpose of investment and its collection of SFDP at Bokhim, Bhojpur

(in '000)

\begin{tabular}{|c|c|c|c|c|c|c|c|c|}
\hline \multirow[t]{2}{*}{ Purpose } & \multicolumn{2}{|c|}{ Investment } & \multicolumn{2}{|c|}{ Collection } & \multirow{2}{*}{$\begin{array}{l}\text { Collection } \\
\text { Exceed } \\
\text { Certain time } \\
\text { period }\end{array}$} & \multirow{2}{*}{$\begin{array}{l}\text { Remaining } \\
\text { investment }\end{array}$} & \multirow{2}{*}{$\begin{array}{c}\text { Exceed } \\
\text { certain } \\
\text { fixed } \\
\text { period }\end{array}$} & \multirow[t]{2}{*}{$\%$} \\
\hline & Aim & Progress & Aim & Progrexs & & & & \\
\hline Major Crops & 450 & 676 & 299 & 426 & 40 & 633 & 55 & 9 \\
\hline Cash Crops & 180 & 335 & 89 & 256 & 17 & 98 & 83 & 84 \\
\hline Special Crops & 10 & - & 6 & 1 & - & 31 & 7 & 22 \\
\hline Agro Business & 25 & 33 & 37 & 26 & - & 41 & 19 & 46 \\
\hline $\begin{array}{l}\text { Agriculture } \\
\text { Inputs }\end{array}$ & 200 & 153 & 101 & 154 & 35 & 284 & 76 & 26 \\
\hline Irrigation & 110 & 165 & 38 & 115 & 4 & 89 & 5 & 5 \\
\hline $\begin{array}{l}\text { Land } \\
\text { Development }\end{array}$ & 5 & - & 9 & 4 & 2 & 14 & 11 & 78 \\
\hline $\begin{array}{l}\text { Collage } \\
\text { Industry }\end{array}$ & 5 & - & 7 & 5 & 3 & 27 & 27 & 100 \\
\hline $\begin{array}{l}\text { Agriculture } \\
\text { Work }\end{array}$ & 810 & 732 & 694 & 624 & 108 & 1436 & 356 & 25 \\
\hline Husbandry & 5 & - & - & - & - & 8 & - & - \\
\hline $\begin{array}{l}\text { House } \\
\text { Building }\end{array}$ & - & - & 28 & - & - & 75 & 62 & 83 \\
\hline
\end{tabular}

Source: SFDP, (Fiscal Year 2052/53 B.S.) Bokhịm, Bhojpur. 
Table - 2: The investment, purpose of investment and its collection

\begin{tabular}{|c|c|c|c|c|c|c|c|c|}
\hline \multirow[t]{2}{*}{ Purpose } & \multicolumn{2}{|c|}{ Investment } & \multicolumn{2}{|c|}{ Collection } & \multirow{2}{*}{$\begin{array}{l}\text { Collection } \\
\text { Exceed } \\
\text { Certain time } \\
\text { period }\end{array}$} & \multirow{2}{*}{$\begin{array}{l}\text { Remaining } \\
\text { investment }\end{array}$} & \multirow{2}{*}{$\begin{array}{c}\text { Exceed } \\
\text { certain } \\
\text { fixed } \\
\text { period }\end{array}$} & \multirow[t]{2}{*}{$\%$} \\
\hline & Aim & Progess & Aim & Progess & & & & \\
\hline Major Crops & 650 & 659 & 616 & 642 & 111 & 649 & 60 & \\
\hline Cash Crops & 200 & 165 & 54 & 167 & 37 & 96 & 65 & \\
\hline Special Crops & - & 5 & 12 & 2 & - & 34 & 9 & \\
\hline Agro Business & 50 & 41 & 30 & 25 & 5 & 57 & 24 & \\
\hline $\begin{array}{l}\text { Agriculture } \\
\text { Inputs }\end{array}$ & 200 & 219 & 121 & 95 & 5 & 408 & 75 & \\
\hline Irrigation & 50 & 89 & 48 & 94 & - & 84 & 3 & \\
\hline $\begin{array}{l}\text { Land } \\
\text { Development }\end{array}$ & $\overline{-}$ & - & 1 & 1 & - & 13 & 11 & \\
\hline $\begin{array}{l}\text { Cottage } \\
\text { Industry }\end{array}$ & - & - & - & - & - & 27 & 27 & \\
\hline $\begin{array}{l}\text { Agriculture } \\
\text { Work }\end{array}$ & 950 & 657 & 502 & 58 & 87 & 1535 & 351 & \\
\hline Husbandry & 10 & - & $=$ & - & 2 & $\overline{8}$ & - & \\
\hline $\begin{array}{l}\text { House } \\
\text { Building }\end{array}$ & - & $\because$ & - & ? & - & 75 & 75 & \\
\hline Total: & 2110 & 1835 & $=$ & $=$ & 245 & 2986 & 710 & 24 \\
\hline
\end{tabular}

Source: SFDP (Fiscal Year 2053/54 B.S.) Bokhim Bhojpur.

The investment and collection of SFDP of Bokhim VDC. According to the datas the investment and collection have shown effective in the fiscal year 2052/053 and 2053/054 because the aim of investment in major crops is 450 and 650 thousand but the actual investment is 676 and 659 thousands in the fiscal year 2052/053 and 2053/054 respectively. It shows the increasement of agriculture activity, which helps to increase the level of income. Similarly the investment is effectively increased in cash crops, agro-business, agriculture input, irrigation. But the data shows the farmers has not taken interest in special crops because the aim of investment is 10 thousands in the fiscal year 2052/053 but the progress is nil. In the fiscal year 2053/054 Rs. 5 thousands are invested in special crops. According to special crops, the loan is invested for the development of Alaichi, Amliso, Aduwa etc. The above datas show the special crops have not developed so much. Cottage industry is another special source to increase the level of income but the loan investment is nil for the establishment and development of cottage industry. Therefore the farmers have not raise income rapidly.

The collection rate is shown more effective in the last two years which is shown by the above table. But the last long years the loan is remaining as a form of investment which can not be collected in the certain fixed period. The 
above table shows 701 and 710 thousand loan is exceeded the certain time period in the fiscal year 2052/053 and 2053/054 respectively. It shows the misused of loan which is not used for the income generating work or the farmer could not earn income by the investment. These different causes show the level of income has not raised rapidly in Bokhim VDC by the investment of SFDP.

\section{CONCLUSION}

'Agriculture is the backbone of Nepalese development,' This proverb is mostly applied in Bokhim VDC. Because most of the people depend upon agriculture, there are no other industrial and commercial activities. The Bokhim VDC is a 'vegetable garden' of Bhojpur bazar. Development of agriculture depends among other things upon supply of adequate, cheap and timely finance. The introduction of SFDP in this VDC small farmers get loan in time and become able to cultivate in time and developed the animal husbandry.

In this way, small farmers have been benefited by the agriculture loan provided by SFDP. The farmers has raised their production so here is seen positive impact of SFDP loan for the agriculture development of Bokhim VDC.

In the field of education and health there is seen positive impact of SFDP in this VDC because SFDP has been financed to make a roof of school and it has conducted adult education programme also to minimize the illiterate problem. This programme has been increased the numbers of literate and conscious person in this VDC. The consciousness of the people has increased by public health training programme, which was organized in different time in the VDC. After conducting this programme very large numbers of farmers have made pit latrines, raising consciousness for cleaning the house, fresh drinking water, increasing family income, childcare, and to adopt the family planning programme for small families. Impact of SFDP in the field of education and public health has been seen positive impact. But in the field of cottage industry SFDP could not play a vital role for the development of this sector. So there is seen negative impact in cottage industry, employment and income generating programme. So it is necessary that SFDP must be organized different skim of cottage industry and financed sufficient capital for the conduct of such kind of industry. By this programme SFDP try to raise employment and income of the people.

Nepal is a country of small farmers and agriculture has remained to be the major occupation of the country. Thus it is obvious that the real development of the kingdom is possible only if these rural masses are made economically sound and self-reliant. Keeping this in mind SFDP has been introduced in Nepal since 1975. The first two Pilot Projects of SFDP were initiated in Mahendra Nagar of Dhanusha district in August 1975 and Tupche of Nuwakot district 


\section{IMPACT OF SFDP UNDER ADB}

March 1976. Now the SFDP has been undertaken by ADB/N covering 75 districts and $631 \mathrm{VDC}$ of this kingdom. The total number of groups formed

under thse projects has reached 3.500 and benefiting 2,21,346 farmers families

The SFDP was introduced in the year 2036 B.S. in Bokhim VDC. It is working actively at that time period. Bokhim VDC is ahead in both the average size of land holding and literacy rate. The average per-capita daily expenditure of the small farmers have come to be approximately Rs. 56 and income is Rs. 20 . Thus the gap between income and expenditure figures shows a negative balance of $50 \%$ of the small farmer households are unable to meet their basic minimum needs. Majority of the small respondents are found to have stated that agricultural production has not been raised after the implementation of SFDP in Bokhim VDC. Majority of small peasant's respondents is found to have received agricultural loan for the cultivation of different crops. But the repayment of loan by the small farmer is found to be poor. This may be due to the lack of adequate generation of income by the small farmers of Bokhim VDC. The main reasons are lack of improvement in the farm yield may be due to the lack of availability of loan in time, inadequate irrigation facilities and training. Higher rate of interest on the project of loan and the burden of outside loans to the small farmers are also major problems. The cottage industry sector seems to be nil stage in Bokhim VDC. Without its development, significant improvement on income and employment of the small farmers can not be expected.

Almost 75 percents of the people of Nepal are small farmers. Therefore, the poverty elevation programmes such, as SFDP needs to be expanded and widened in a planned and systematic way. Poverty, ignorance and disease are the common problems of the small farmers and the nation alike. These multiple problems need to be tackled by giving due emphasis to the basic needs approach to development.

\section{WORKS CITED}

Acharya, Pitamber Prasad (1980), Small Farmers Development Programme, an experiences in rural development, Nepal.

Agrawal, Govinda Ram (1981), Small Farmers Group marketing, CEDA.

Agriculture Development Bank in Nepal (1979), Small Farmers Development Programme operational manual, Katl. .andu.

Nepal Rastra Bank, "An evaluation of small Farmers Development Programme 1982", Kathmandu, Nepal.

Suwal, Rajendra, (1980), Small Farmers Development Programme, A case study, CEDA. 